\title{
H2AC18 Gene
}

National Cancer Institute

\section{Source}

National Cancer Institute. H2AC18 Gene. NCI Thesaurus. Code C162962.

This gene is involved in the maintenance of chromatin. 